\title{
А.П. Чоботар
}

\section{АКАНТАМЕБИ ЯК РЕЗЕРВУАР ПАТОГЕННИХ БАКТЕРІЙ TA BIPУCIB}

\author{
Національний медичний університет ім. О.О. Богомольця
}

Огляд літератури показав, що вільноживучі найпростіші роду Acanthamoeba $є$ представниками багатьох об'єктів зовнішнього середовища та постійно взаємодіють з іншими мікроорганізмами (вірусами та бактеріями), що населяють дані екологічні ніші. Особливості цих взаємовідносин вивчаються дослідниками з усього світу вже більше 20 років. Досліджено низку патогенних та умовно-патогенних бактерій, які здатні співіснувати з акантамебами. Так, наприклад, описано симбіотичну взаємодію амеб з ентеробактеріями, мікобактеріями, легіонелами, псевдомонадами, стафолококами, стрептококами та рядом інших прокаріот. При співкультивуванні найпростіших з бактеріями збільшується термін виживання останніх та підвищується їх резистентність до впливу шкідливих фракторів навколишнього середовища. Ряд наукових робіт присвячено також вивченню взаємодії Acanthamoeba sp. $з$ представниками царства Vira, а саме родів Adenovirus, Norovirus, Rotavirus ma Enterovirus. Характер взаємодії бактерій та вірусів із представниками вільноживучих найпростіших на клітинному рівні досліджується найчастіше з використанням мікроскопічних і сучасних молекулярно-генетичних методів. Доведено також, що вільноживучі амеби можуть виконувати роль резервуару для патогенних мікроорганізмів та слугувати вектором передачі збудників інфекційних захворювань.

Ключові слова: Acanthamoeba sp., співіснування, бактерії, віруси.

Акантамеби - вільноживучі найпростіші, які мають убіквітарне поширення та населяють різноманітні екосистеми, такі як ґрунт, вода, повітря. Вони були ізольовані із басейнів, водопровідних мереж, охолоджувальних і стоматологічних установок, апаратів для гемодіалізу, медичних засобів (рідина для лінз) та ін. [1, 2]. Серед вільноживучих амеб тільки чотири роди включають умовно-патогенних для людини та тварин представників: Acanthamoeba, Balamuthia, Naegleria i Sappinia. Ïх таксономічне положення було кілька разів переглянуте відповідно до критеріїв сучасної систематики. Опираючись на класифрікацію, яка запропонована Міжнародним товариством протозоологів, дані мікроорганізми були поміщені в так звані «супергрупи». Acanthamoeba та Balamuthia були віднесені до супергрупи Amoebozoa: Acanthamoevidae; Naegleria fowleri до Excavata: Heterolobosia: Vahlkampfiidae; i Sappinia до Amoebozoa: Flabellinea: Thecamoevidae [2]. Вільноживучі амеби здатні спричиняти такі захворювання у людей: амебний кератит, гранулематозний енцефаліт, менінгіт і менінгоенцефаліт, синусити, шкірні ураження та ін. [2-6].

Більшість вільноживучих амеб має дві морфологічні фрорми: вегетативну - трофозоїт, і неактивну - циста. Вичерпання поживних речовин у вогнищі перебування амеб або дія інших екологічних стресових фракторів, таких як зміна $\mathrm{pH}$, температури, насиченості киснем середовища, різке зменшення вологості сприяють перетворенню трофозоїтів у цисти. Цей процес називається інцистування. Цисти амеб стійкі до ряду несприятливих фрізико-хімічних фракторів. Показано також, що зрілі цисти вільноживучих амеб стійкіші до дезінфрікуючих засобів і біоцидів, ніж трофрозоїти [7].

Взаємодія акантамеб з бактеріями. Під час дослідження вільноживучих найпростіших було виявлено низку бактерій та вірусів, які можуть перебувати всередині амебної клітини. Описано специфрічну здатність амеб захоплювати мікроби та зберігати їх в цитоплазмі, таким чином захищаючи від стресових фракторів навколишнього середовища $[1,2]$. Як відомо, еукаріотичні клітини можуть поглинати речовини шляхом піноцитозу (в розчиненому стані) та фрагоцитозу (в твердому стані). Останній, як правило, здійснюється при розмірах часток $\leq 250$ нм, включаючи клітини бактерій та інші клітинимішені [8]. Враховуючи те, що акантамеби захоплюють мікроорганізми шляхом фрагоцитозу, було висунуто припущення про спільну функціональну еволюцію амеб і компонентів мікро-макрофрагальної системи багатоклітинних організмів, безпосередньо макрофрагів. Проведені експериментальні роботи показали подібність даних типів клітин в ультраструктурних морфологічних 
особливостях, біохімічних властивостях, здатності до активного руху та використанні псевдоподій для захоплення твердих часток [9]. Описано застосування вільноживучих найпростіших як модель для дослідження явища фрагоцитозу в умовах in vitro [10]. Разом 3 тим, Maisonneuve E. et al., на прикладі аденовірусів з використанням мікроскопічних і молекулярно-генетичних методів, показали, що реплікація вірусу відбувається лише в макрофрагах і відсутня в акантамебах. Також було встановлено, що наявність вірусу знижує життєздатність макрофрагів і не впливає на амеби. Саме тому найпростіші не можуть використовуватись як повністю адекватна модель для вивчення фрагоцитозу [11].

На основі цього рядом авторів було зроблено висновок, що амеби є природним резервуаром різноманітних інфекційних агентів і діють як «троянські коні» мікробного світу $[11,13]$. Досліджено взаємодію найпростіших з легіонелами, ентеробактеріями, псевдомонадами, мікобактеріями та рядом інших бактерій. Для даних мікроорганізмів також був введений термін амеборезистентні бактерії (АРБ), здатні протистояти фагоцитозу амеб [1, 11, 13]. Описано більше ніж 100 збудників інфекційних хвороб людини, які здатні тривалий час виживати та, навіть, розмножуватися при спільному існуванні з різними видами амеб. Деякі види бактерій можуть уникати дії високих концентрацій дезінфрікуючих та антибактерійних засобів, перебуваючи в трофозоїтах чи цистах найпростіших. В таблиці 1 наведені основні представники патогенних та умовно-патогенних бактерій, які можуть використовувати вільноживучих найпростіших як хазяїна.

Таблиця 1

Патогенні та умовно-патогенні мікроорганізми, які взаємодіють з найпростішими

\begin{tabular}{|c|c|c|}
\hline Родина & Вид & Джерела літератури \\
\hline \multirow[t]{3}{*}{ Enterobacteriaceae } & Escherichia coli & $\begin{array}{l}\text { Matin, A. and Jung, S., [14] } \\
\text { Mehmood K. et al., [15] }\end{array}$ \\
\hline & $\begin{array}{l}\text { Salmonella enterica: } \\
\text { serovar Dublin, } \\
\text { serovar Enteritidis, } \\
\text { serovar Typhimurium } \\
\text { serovar Typhi }\end{array}$ & $\begin{array}{l}\text { Tezcan-Merdoe, D. et al., [16] } \\
\text { Douesnard-Malo, F., \& Daigle, F., [17] }\end{array}$ \\
\hline & $\begin{array}{l}\text { Shigella dysenteriae } \\
\text { Shigella sonnei } \\
\text { Shigella flexneri }\end{array}$ & $\begin{array}{l}\text { Saeed A, Abd, H. et.al., [18] } \\
\text { Saeed, A., Johansson, D. et.al., [19] }\end{array}$ \\
\hline Legionellaceae & Legionella pneumophila & $\begin{array}{l}\text { Anand, C. et al., [20] } \\
\text { C. Harold King et al., [21] } \\
\text { Mengue, L. et al., [22] } \\
\text { Adeleke, A. et al., [23] }\end{array}$ \\
\hline \multirow[t]{5}{*}{ Mycobacteriaceae } & Mycobacterium tuberculosis & Mba Medie, F. et al., [24] \\
\hline & Mycobacterium avium & Samba-Louaka, A. et al., [25] \\
\hline & Mycobacterium leprae & Wheat, W. et al., [26] \\
\hline & Mycobacterium smegmatis & Lamrabet, O. et al., [27] \\
\hline & Mycobacterium bovis & Sanchez-Hidalgo, A. et al., [28] \\
\hline Pseudomonadaceae & Pseudomonas aeruginosa & Pukatzki, S. et al., [29] \\
\hline Staphylococcaceae & $\begin{array}{l}\text { Methicillin-Resistant Staphylococcus au- } \\
\text { reus } \\
\text { (MRSA) }\end{array}$ & De Souza, T. et al., [30] \\
\hline Streptococcaceae & $\begin{array}{l}\text { Streptococcus pneumoniae } \\
\text { Streptococcus pyogenes }\end{array}$ & Siddiqu, R. et al., [31] \\
\hline Vibrionaceae & Vibrio cholerae & $\begin{array}{l}\text { Abd, H., Saeed, A. et al., [32] } \\
\text { Abd, H., Saeed, A. et al., [33] }\end{array}$ \\
\hline
\end{tabular}




\section{Родина Enterobacteriaceae}

Симбіотичні взаємовідносини між ентеробактеріями та вільноживучими амебами було досліджено на прикладі багатьох представників різних родів цієї родини.

\section{Pid Escherichia}

Для дослідження здатності акантамеб поглинати та зберігати бактерії роду Escherichia, їх культивували спільно з Escherichia coli K1, K5 та К12. Після обробки антибіотиками визначали життєздатність бактерій. Різке зменшення, або повна відсутність чутливості ешерихій до протимікробних лікарських засобів свідчили про можливість їх потрапляння всередину амебної клітини $[14,15]$. В результаті було показано, що штами К1 та К5 поглинались амебною клітиною, залишались життєздатними у внутрішньому клітинному середовищі та, навіть, могли розмножувались. Було виявлено, що зовнішній мембранний білок A (OmpA) і ЛПС клітинної стінки бактерій є вирішальними детермінантами, що відповідають за можливість поглинання амебою E. coli K1 [14]. Штам К12 після захоплення амебою повністю перетравлювався, саме тому цей тип E. coli застосовують як годувальників для культивування деяких найпростіших [3]. Таким чином було показано, що окремі штами E. coli здатні виживати всередині акантамеб і використовувати їх як свій резервуар.

\section{Pid Salmonella}

Співкультивування бактерій виду Salmonella enterica: серовари typhi, typhimurium, enteritidis та dublin з вільноживучими амебами доводить наявність симбіотичних відносин між даними мікроорганізмами. Це явище підтверджено такими методами, як проточна цитофлуорометрія, фрлуоресценцентна та електронна мікроскопія. Показано, що бактерії зберігають свою життєздатність після тривалого співкультивування 3 найпростішими. Результати, представлені авторами, переконливо доводять, що при культивуванні S. enterica серовар typhi спільно з A. castellanii бактерії можуть зберігати свою життєздатність протягом 3 тижнів при температурі $30^{\circ} \mathrm{C}$ у середовищі PYG, порівняно 3 контролем - 10 діб при самостійному культивуванні бактерій за тих же умов. Варто також відзначити, що темпи росту амеб після 14 діб не змінювались. Це вказує на те, що S. typhi не має цитотоксичного впливу на A. castellanii. Ці результати демонструють те, що пов'язані з A. castellanii бактерії є більш стійкими і амеби можуть сприяти збереженню сальмонел у навколишньому середовищі [17].

\section{Pid Shigella}

Можливість співіснування Sh. dysenteriae i Sh. sonnei з Acanthamoeba castellanii було підтверджено шляхом підрахунку життєздатних бактерійних клітин після впливу антибіотика (гентаміцин) на суміш амеби-бактерії та з подальшим використанням електронної мікроскопії.
Отримані результати експериментального дослідження показали, що Sh. dysenteriae та Sh. sonnei також здатні виживати в присутності амеб більше 3 тижнів. Використані шигели були не чутливими до впливу антимікробного препарату, а отже знаходилися всередині клітини Acanthamoeba castellanii, що було наочно продемонстровано за допомогою електронної мікроскопії: бактерії чітко візуалізувалися в цитоплазмі $A$. castellanii. Отже, цілком ймовірно, амеби відіграють значну роль у передачі бактерій роду Shigella в навколишньому середовищі [18]. Saeed A. et al. використовували Acanthamoeba castellanii як модель для вивчення вірулентності бактерій роду Shigella. Авторами було показано, що шигели за наявності різних фракторів патогенності мають здатність контролювати спосіб загибелі клітин-хазяїнів, оскільки вони прямо активували механізми, що призводили до апоптозу або некрозу амеб [19].

\section{Родина Legionellaceae}

В ряді літературних джерелах описано симбіотичні зв'язки L. pneumophila з вільноживучими найпростішими родів Hartmanella та Acanthamoeba. 3 використанням електронно-мікроскопічних та імунофрлуоресцентних методів лабораторного дослідження було показано, що L. pneumophila розмножувалась тільки всередині трофрозоїтів амеб. Методом електронної мікроскопії досліджено можливі варіанти розташування легіонел у внутрішньоклітинному середовищі найпростіших. Бактерії визначалися у фагосомах (включаючи клітини, що діляться), заповнювали цитоплазму або знаходились в інших частинах амебної клітини під час їх процесу інцистування [20, 21]. Було показано, що акантамеби активно захоплювали і перетравлювали легіонели при температурі $20^{\circ} \mathrm{C}$. Бактерії зникали з культурального середовища на 2-у добу при спільному культивуванні, проте до 6-ї доби знову з'являлись у середовищі в невеликій концентрації (10² КУО/мл). Отже легіонели здатні до розмноження всередині амебної клітини та таким чином зберігають свою життєздатність [20]. Згідно 3 літературними даними, легіонели, перебуваючи в цитоплазмі найпростіших, можуть перешкоджати поділу клітини та реплікації ДНК останніх, а також змінювати їх морфологію [22]. Крім L. pneumophila досліджені легіонело-подібні амебні патогени (LLAPs), які ізолювалися з клітин найпростіших. Свою назву вони отримали через схожу з легіонелами здатність до інвазії та розмноження в клітинах вільноживучих найпростіших. Вважається, що LLAPs $€$ обов'язковими внутрішньоклітинними бактерійними паразитами вільноіснуючих амеб [23].

\section{Родина Mycobacteriaceae}

Акантамеби вже тривалий час розглядають як резервуар мікобактерій у навколишньому середовищі. Для вивчення особливостей взаємодії представників родини 
Mycobacteriaceae та амеб були використані такі види: Mycobacterium tuberculosis, Mycobacterium avium, Mycobacterium leprae та Mycobacterium bovis [24-28]. Було встановлено, що всі мікобактерії здатні виживати в клітині амеби як на стадії трофозоїта, так і цисти. Samba-Louaka A. et al. для визначення наявності M. avium підвиду paratuberculosis в амебах, які перебувають в навколишньому середовищі, відбирали зразки води фрермерських угідь, де реєструвався паратуберкульоз серед тварин. Проведені молекулярно-генетичні дослідження показали, що в амебах і зразках від хворих тварин виділені тотожні бактерії. Це явище підтверджує, що амеби можуть бути вектором передачі даного інфекційного захворювання [25]. Важливим $€$ також фракт збереження вірулентності штамів бактерій після взаємодії з найпростішими. Wheat W. et al. в експерименті 3 білими мишами, яким вводили Mycobacterium leprae після 35-денного співкультивування 3 A. castellanii та A. polyphaga показали, що у більшості тварин (80 \%) з'явились ознаки захворювання. При мікроскопічному дослідженні біологічного матеріалу, взятого в лабораторних тварин, виявлено кислото-стійкі бактерії, приналежність яких до мікобактерій було підтверджено молекулярно-генетичними методами (ПЛР) [26]. Ці дані дозволяють зробити висновок про те, що мікобактерії можуть довготривало залишатися життєздатними у вільноживучих амебах і зберігати свою вірулентність.

\section{Pодина Pseudomonadaceae}

Для визначення взаємовідносин вільноживучих амеб з бактеріями роду Pseudomonas sp. використовували 12 різних видів амеб. В результаті проведених молекулярно-генетичних досліджень з усіх зразків суспензій амеб була виділена ДНК псевдомонади [29]. Даний експеримент доводить належність псевдомонад до ряду бактерій, які здатні співіснувати з вільноживучими найпростішими.

\section{Родина Staphylococcaceae}

Здатність взаємодії між Acanthamoeba polyphaga i Staphylococcus aureus (MRSA) визначали шляхом тривалого спільного культивування бактерій та найпростіших. Амеби та стафрілококи вирощували протягом 96 год при $30{ }^{\circ} \mathrm{C}$, відбираючи зразки через рівні проміжки часу $(24,48,72,96$ год). Результати показали, що при контакті бактерій з найпростішими за даних умов існування кількість життєздатних амебних клітин знижувалася до 89 \%, в той час як розвиток стафрілококів при контакті 3 трофозоїтами покращувався. Було також встановлено, що лізат амебної культури (отриманий після 3 циклів заморожування при $-20^{\circ} \mathrm{C}$, з подальшим розморожуванням) збільшує інтенсивність росту золотистого стафрілокока, а супернатант амебної культури пригнічує ріст бактерій. Дане явище вказує на те, що A. polyphaga утворює певні метаболіти, які впливають на інтенсивність росту бактерій. Поряд з тим, описано збільшення часу інцистування A. polyphaga в присутності бактерій S. aureus. Таким чином, отримані результати показують, що A. polyphaga та S. aureus мають виражений взаємний вплив на розвиток і метаболізм один одного [30].

\section{Родина Streptococcaceae}

При вивченні взаємодії S. pyogenes i S. pneumoniae з найпростішими виду A. castellanii було показано, що обидва види стрептококів могли адсорбуватися на поверхні амебного трофозоїта, а також проникати в амебу та/або захоплюватись нею. Варто зазначити, що S. pyogenes i S. pneumoniae зберігали свою життєздатність в процесі інцистування, уникали перетравлення, розмножувались всередині амебних клітин і проявляли більшу стійкість у зрілих цистах, порівняно зі стадією трофозоїта. Як і в ряді інших випадків, авторами показано, що A. castellanii також може виступати як вектор та/або резервуар для стрептококів, сприяючи їхньому росту та частковому обміну генетичною інфрормацією між ними. Крім того, дослідниками висунуто припущення, що даний тип взаємодії не лише сприяє виживанню S. pyogenes i S. pneumoniae у навколишньому середовищі, а також впливає на їх вірулентність [31].

\section{Родина Vibrionaceae}

Вивчення взаємодії V. cholera з представниками вільноживучих найпростіших має важливе практичне значення. Як відомо, збудник холери передається в основному через водне середовище, яке інтенсивно заселяють вільноіснуючі амеби. Дослідження останніх років доводять, що V. cholerae серовар O139 має внутрішньоклітинну сумісність з Acanthamoeba castellanii як еукаріотичним хазяїном. Дане явище було підтверджено із застосуванням V. cholera серологічної групи О1 (біовари classic та El Tor). Обидва біовари могли виживати, перебуваючи в цитоплазмі трофозоїтів, а також були виявлені в цистах A. castellanii. Одержані результати дали змогу авторам зробити висновок, що V. cholerae O1 біоварів classic та El Tor є фракультативними внутрішньоклітинними бактеріями, а A. castellanii є потенційним хазяїном для холерного вібріона [32]. Вивчаючи вплив фракторів адгезії та інвазії V. cholera 0139 Bengal (капсула та ЛПС) на розвиток цих бактерій всередині амебної клітини, було показано, що жоден з вищенаведених факторів не впливав на симбіотичну взаємодію вібріонів і найпростіших [33]. Отже, вільноживучі амеби можуть виступати хазяїном і для даних бактерій у довкіллі, а фрактори вірулентності V. cholera не впливають на взаємодію найпростіших і вібріонів.

Дослідження взаємодії вільноживучих амеб з представниками мікробного світу не обмежилося лише використанням бактерій. Зокрема, ряд наукових робіт 
присвячено вивченню можливої взаємодії вільноживучих амеб з патогенними для людей вірусами. У ході визначення здатності до співіснування даних мікроорганізмів постало питання про можливість амеб захоплювати вірусні частки, оскільки розміри практично всіх патогенних для людей вірусів, на відміну від бактерій, не перевищують межу фрагоцитозу ( $\leq 250$ нм). Саме тому деякі автори досліджували взаємодію амеб не лише з віріонами, а також з клітинами, що уражені вірусом.

\section{Pid Adenovirus}

Аденовіруси - патогенні для людини віруси, що викликають такі захворювання, як респіраторні інфекції, фрарингокон'юнктивальна гарячка, кон'юнктивіти, гастрити, цистити та ін. Для вивчення взаємодії аденовірусів 3 акантамебами використовували найпростіші (генотип T4), ізольовані з водопровідної води та води плавальних басейнів, а також амеби з патогенним потенціалом від пацієнтів з амебним кератитом (штам LaHel2). Акантамеби культивували разом 3 аденовірусами 1, 2, 8, 11, 37, та 41 серотипів [34-36]. 3 використанням електронної та фрлуоресцентної мікроскопії було показано, що віруси після контакту з амебами локалізувалися в цитоплазмі трофрозоїтів [34]. В наступних дослідженнях ідентифрікація проводилась методом полімеразної ланцюгової реакції в реальному часі. Застосування даного підходу дозволило визначити генетичний матеріал аденовірусу в 62,5 \% амебних ізолятів [35]. Отже, враховуючи вищенаведені дані, можна зробити висновок, що аденовіруси потрапляють в клітинне середовище амеб на стадії трофрозоїта, а, перебуваючи всередині цисти, віруси, як і бактерії, захищені від дії різних пошкоджуючих фракторів, включаючи дезінфектанти.

\section{Pid Norovirus}

Одним 3 найпоширеніших збудників гострих вірусних кишкових інфекцій є норовіруси (норфолквіруси), які передаються через забруднену їжу або воду. Як і у випадку з холерним вібріоном, вивчення взаємодії акантамеб з норовірусами є важливим питанням, оскільки вільноживучі амеби, постійно перебуваючи у водному середовищі, мають контакт з вірусними агентами. A, отже, можуть відігравати значну роль в епідеміологічному процесі поширення цієї інфекції. Для підтвердження такої гіпотези в дослідженнях використали два види амеб: A.castellanii та A.polyphaga, а також похідні норовірусів - мишачий норовірус 1 (MNV-1) і котячий каліцивірус (FCL). Для індикації взаємодії використовували реакцію імуносрлуоресценції, яка була проведена через 1 та 24 год після контакту обох агентів. В результаті проведеного дослідження було встановлено, що у вірусу MNV-1 процес переходу від зовнішньої поверхні амеби до її внутрішньої частини завершується вже через 24 год, в той час як FCL не виділявся вже через 1 год.
Крім того, було досліджено тривалу взаємодію вірусу (протягом 8 діб) MNV-1, і показано, що вірус виживає після проходження амебою повного життєвого циклу (інцистування та ексцистування) [37]. Отже вільноживучі амеби можуть сприяти підвищенню виживання норовірусів, як і ряду інших мікробних агентів.

\section{Pid Enterovirus}

Представники ентеровірусів здатні викликати низку інфекційних захворювань, вражаючи як травну, так і нервову систему. Серед ентеровірусів для визначення взаємодії з вільноіснуючими найпростішими використовували віруси Коксакі, ЕСНО та поліовірус. Експерименти з вірусом Коксакі В-3 (CVB-3), які оцінювали за допомогою реакції імунофрлуоресценції, показали чудову адсорбцію вірусів на поверхні амеби та накопичення їх всередині трофозоїтів. Виживання вірусних агентів не залежало від динаміки реплікації амеб та їх інцистування. Крім того, результати експериментальної роботи показали, що вірус-інфіковані амеби можуть вивільняти інфекційні вірусні частки під час взаємодії їх з макрофрагами людини [38]. Подальше вивчення взаємодії вірусів Коксакі та акантамеб, проведене Alotaibi M., мають протилежні результати. В даному дослідженні автор показав, що ентеровіруси здатні потрапляти в трофозоїти вільноживучих амеб лише в поєднанні з інфрікованими клітинами ссавців, а не самостійно. Результати були отримані за допомогою молекулярно-генетичних та імунофрлуоресцентних методів [39]. Danes L. та Cerva L. в умовах in vitro контамінували вирощену при кімнатній температурі Acanthamoeba castellanii людськими ентеровірусами (ЕСНО 4, 30 та поліовіруси 1 і 3 серотипу). Авторами не було відзначено значного накопичення ентеровірусів на поверхні чи всередині амебної клітини при 21-денному спостережені. На основі реакції нейтралізації із специсічними сироватками дослідниками був зроблений висновок, що віруси швидше за все знаходяться лише на поверхні амебної клітини. Таким чином, на думку авторів, клітинні форми найпростіших відігравали для вірусів лише роль твердофазного носія [40].

\section{Pid Rotavirus}

На сьогодні ротавіруси є найбільш поширеними збудниками вірусних кишкових інфекцій як серед дітей, так і дорослих. Оскільки віруси у великій кількості виділяються з фрекаліями інфікованих пацієнтів у зовнішнє середовище, то актуальним є вивчення здатності їх до взаємодії з вільноживучими найпростішими. Проведені експериментальні мікроскопічні (імуноорлоресценція) дослідження показують, що трофозоїти амеб можуть захоплювати клітини, які іноріковані ротавірусами, натомість вільні вірусні частки не здатні проникати в клітини акантамеб. Таким чином, найпростіші роду Acanthamoeba можуть бути переносниками ротавірусів 
у людській популяції, оскільки при ротавірусних інфекціях вірус виділяється разом з інфікованими епітеліальними клітинами та надходить у стічні води, де і перебувають амеби [39].

Таким чином, на основі всебічного аналізу джерел літератури можна зробити висновок, що вільноживучі найпростіші мають специфрічні способи взаємодії з різноманітними патогенними та умовно-патогенними мікроорганізмами. Результати численних експериментальних досліджень підтверджують, що акантамеби можуть виконувати роль резервуару для багатьох збудників інфрекційних захворювань, а також бути фрактором передачі їх до людей або тварин. Патогенні бактерії та віруси, які локалізуються в амебах, несуть приховану загрозу для здоров'я людей, оскільки вони є недосяжними для медикаментів і нечутливі до дії згубних зовнішніх чинників і дезінфектантів.

\section{Література}

1. Greub, G. Microorganisms Resistant to Free-Living Amoebae / Greub, G., \& Raoult, D. // Clinical Microbiology Reviews. - 2004. 17(2). - P. 413-433.

2. Balczun, C. Free-Living Amoebae as Hosts for and Vectors of Intracellular Microorganisms with Public Health Significance / Balczun, C., \& Scheid, P. // Viruses. - 2017. - 9(4). - P. 65.

3. Khan, N. Acanthamoeba: biology and increasing importance in human health / Khan, N. // FEMS Microbiology Reviews. - 2006. - 30(4). - P. 564-595.

4. da Rocha-Azevedo. Diagnosis of Infections Caused by Pathogenic Free-Living Amoebae / da Rocha-Azevedo, B., Tanowitz, H., \& Marciano-Cabral, F. // Interdisciplinary Perspectives On Infectious Diseases. - 2009. - P. 1-14.

5. Behera, H. Isolation and genotyping of Acanthamoeba spp. from Acanthamoeba meningitis / meningoencephalitis (AME) patients in India / Behera, H., Satpathy, G., \& Tripathi, M. // Parasites \& Vectors. $-2016 .-9(1) .-6 \mathrm{p}$.

6. Parasitic Sinusitis and Otitis in Patients Infected with Human Immunodeficiency Virus: Report of Five Cases and Review / [Dunand, V., Hammer, S., Rossi, R. et al.] // Clinical Infectious Diseases. - 1997. - 25(2) . - P. 267-272.

7. Lambrecht, E. Impact of Acanthamoeba Cysts on Stress Resistance of Salmonella enterica Serovar Typhimurium, Yersinia enterocolitica 4/O:3, Listeria monocytogenes 1/2a, and Escherichia coli O:26 / Lambrecht, E., Baré, J., Sabbe, K., \& Houf, K. // Applied And Environmental Microbiology. - 2017. - 83(14). - 9 p.

8. Avalos-Padilla, Y. The Conserved ESCRT-III Machinery Participates in the Phagocytosis of Entamoeba histolytica / Avalos-Padilla, Y., Knorr, R., Javier-Reyna, R., García-Rivera, G., Lipowsky, R., Dimova, R., \& Orozco, E. // Frontiers In Cellular And Infection Microbiology. 2018. -8 .

9. Siddiqui, R. Acanthamoeba is an evolutionary ancestor of macrophages: A myth or reality? / Siddiqui, R., \& Khan, N. // Experimental Parasitology. - 2012. - 130(2). - P. 95-97.

10. Cosson, P. Intracellular killing of bacteria: is Dictyostelium a model macrophage or an alien? / Cosson, P., \& Lima, W. // Cellular Microbiology. - 2014. - 16(6). - P. 816-823.

11. Maisonneuve, E. Acanthamoeba castellanii is not be an adequate model to study human adenovirus interactions with macrophagic cells / Maisonneuve, E., Cateau, E., Leveque, N., Kaaki, S., BebyDefaux, A. \& Rodier, M. // PLOS ONE. - 2017. - 12(6). - P. e0178629.

12. Barker, J. Trojan Horses of the microbial world: protozoa and the survival of bacterial pathogens in the environment /Barker, J., \& Brown, M. // Microbiology. - 1994. - 140(6). - P. 1253-1259.

13. . Molmeret, M. Amoebae as Training Grounds for Intracellular Bacterial Pathogens. / Molmeret, M., Horn, M., Wagner, M., Santic,
M., \& Abu Kwaik, Y. / Applied and Environmental Microbiology. - 2005. - 71(1). - P. 20-28.

14. Matin, A. Interaction of Escherichia coliK1 and K5 with Acanthamoeba castellanii Trophozoites and Cysts /Matin, A., \& Jung, S. // The Korean Journal Of Parasitology. - 2011. - 49(4). - P. 349.

15. Mehmood K. Escherichia coli K5 and type III secretion systems mutant interactions with Acanthamoeba (T4 genotype) / Mehmood K, Gul N, Jung SY, Matin A. // Adv Lab Med Int. - 2012. - 2(1). - P. 25-39.

16. Tezcan-Merdol, D. Uptake and Replication of Salmonella enterica in Acanthamoeba rhysodes / Tezcan-Merdol, D., Ljungstrom, M., Winiecka-Krusnell, J., Linder, E., Engstrand, L., \& Rhen, M. // Applied And Environmental Microbiology. - 2004. - 70(6). - P. 3706-3714.

17. Douesnard-Malo, F. Increased Persistence of Salmonella enterica Serovar Typhi in the Presence of Acanthamoeba castellanii. / Douesnard-Malo, F., \& Daigle, F. // Applied And Environmental Microbiology. - 2011. - 77(21). - P. 7640-7646.

18. Saeed, A. Acanthamoeba castellanii an environmental host for Shigella dysenteriae and Shigella sonnei / Saeed, A., Abd, H., Edvinsson, B., \& Sandström, G. // Archives Of Microbiology. -2008. - 191(1). - P. 83-88.

19. Saeed, A. Temperature Depended Role of Shigella flexneri Invasion Plasmid on the Interaction with Acanthamoeba castellanii / Saeed, A., Johansson, D., Sandström, G., \& Abd, H. // International Journal Of Microbiology. - 2012. - P. 1-8.

20. Anand, C. Interaction of L. pneumophila and a free living amoeba (Acanthamoeba palestinensis) / Anand, C., Skinner, A., Malic, A., \& Kurtz, J. // Journal Of Hygiene. - 1983. - 91(02). - P. 167-178.

21. Effects of Cytochalasin D and Methylamine on Intracellular Growthof Legionella pneumophila in Amoebae and Human MonocyteLike Cells / [C. Harold King, Barry S. Fields et al.] // Infection And Immunity. - 1991. - Vol. 59. - No. 3. - P. 758-763.

22. Legionella pneumophila prevents proliferation of its natural host Acanthamoeba castellanii / Mengue, L., Régnacq, M., Aucher, W., Portier, E., Héchard, Y., \& Samba-Louaka, A // Scientific Reports. $-2016 .-6(1) .-12 \mathrm{p}$.

23. Adeleke, A. Legionella-Like Amebal Pathogens—Phylogenetic Status and Possible Role in Respiratory Disease / Adeleke, A. // Emerging Infectious Diseases. - 1996. - 2(3). - P. 225-230.

24. Mba Medie, F. Mycobacterium tuberculosis Complex Mycobacteria as Amoeba-Resistant Organisms / Mba Medie, F., Ben Salah, I., Henrissat, B., Raoult, D., \& Drancourt, M. // Plos ONE. - 2011. - 6(6). - P. e20499.

25. Environmental Mycobacterium avium subsp. paratuberculosis Hosted by Free-Living Amoebae / [Samba-Louaka, A., Robino, E., Cochard, T., et al.] // Frontiers In Cellular And Infection Microbiology. - 2018. - Vol. 8. -28. 


\section{ОГЛЯДИ ТА ЛЕКЦІї}

26. Long-term Survival and Virulence of Mycobacterium leprae in Amoebal Cysts / [Wheat, W., Casali, A., Thomas, V. et al.] // Plos Neglected Tropical Diseases. - 2014. - 8(12). - P. e3405.

27. Lamrabet, O. Acanthamoeba polyphaga-Enhanced Growth of Mycobacterium smegmatis / Lamrabet, O., Medie, F., \& Drancourt, M. // Plos ONE. - 2012. - 7(1). - P. e29833.

28. Sanchez-Hidalgo, A. Mycobacterium bovis hosted by freeliving-amoebae permits their long-term persistence survival outside of host mammalian cells and remain capable of transmitting disease to mice / Sanchez-Hidalgo, A., Obregón-Henao, A., Wheat, W., Jackson, M., \& Gonzalez-Juarrero, M. // Environmental Microbiology. - 2017 - 19(10). - P. 4010-4021.

29. Pukatzki, S. The human pathogen Pseudomonas aeruginosa utilizes conserved virulence pathways to infect the social amoeba Dictyostelium discoideum / Pukatzki, S., Kessin, R., \& Mekalanos, J. // Proceedings Of The National Academy Of Sciences. - 2002. 99(5). - P. 3159-3164.

30. de Souza, T. Interaction Between Methicillin-Resistant Staphylococcus aureus (MRSA) and Acanthamoeba polyphaga / de Souza T., Soares, S., Benitez, L., \& Rott, M. // Current Microbiology. - 2017. - 74(5). - P. 541-549.

31. Siddiqui, R. Acanthamoeba castellanii interactions with Streptococcus pneumoniae and Streptococcus pyogenes / Siddiqui, R., Yee Ong, T., Jung, S., \& Khan, N. // Experimental Parasitology. - 2017. - 183. - P. $128-132$

32. Abd, H. Vibrio cholerae $\mathrm{O} 1$ strains are facultative intracellular bacteria, able to survive and multiply symbiotically inside the aquatic free-living amoeba Acanthamoeba castellanii / Abd, H., Saeed, A., Weintraub, A., Nair, G., \& Sandstrom, G. // FEMS Microbiology Ecology. - 2007. $-60(1)$. - P. 33-39

\section{References}

1. Greub, G., \& Raoult, D. (2004). Microorganisms resistant to fee-living amoebae. Clinical Microbiology Reviews, 17 (2), 413-433. doi: 10.1128/cmr.17.2.413-433.2004

2. Balczun, C., \& Scheid, P. (2017). Free-living amoebae as hosts for and vectors of intracellular microorganisms with public health significance. Viruses, 9 (4), 65. doi: 10.3390/v9040065

3. Khan, N. (2006). Acanthamoeba: biology and increasing importance in human health. FEMS Microbiology Reviews, 30 (4), 564-595. doi: 10.1111/j.1574-6976.2006.00023.x

4. da Rocha-Azevedo, B., Tanowitz, H., \& Marciano-Cabral, F. (2009). Diagnosis of infections caused by pathogenic free-living amoebae. Interdisciplinary Perspectives on Infectious Diseases, 1-14. doi $10.1155 / 2009 / 251406$

5. Behera, H., Satpathy, G., \& Tripathi, M. (2016). Isolation and genotyping of Acanthamoeba spp. from Acanthamoeba meningitis/ meningoencephalitis (AME) patients in India. Parasites \& Vectors, 9 (1). doi: 10.1186/s13071-016-1729-5

6. Dunand, V., Hammer, S., Rossi, R., Poulin, M., Albrecht, M., \& Doweiko, J. (1997). Parasitic sinusitis and otitis in patients infected with human immunodeficiency virus: Report of five cases and review. Clinical Infectious Diseases, 25 (2), 267-272. doi: 10.1086/514536

7. Lambrecht, E., Baré, J., Sabbe, K., \& Houf, K. (2017). Impact of Acanthamoeba cysts on stress resistance of Salmonella enterica Serovar Typhimurium, Yersinia enterocolitica 4/O:3, Listeria monocytogenes 1/2a, and Escherichia coli O:26. Applied and Environmental Microbiology, 83 (14). doi: 10.1128/aem.00754-17
33. Abd, H., Vibrio cholerae 0139 requires neither capsule nor LPS O side chain to grow inside Acanthamoeba castellanii / Abd, H., Saeed, A., Weintraub, A., \& Sandstrom, G. // Journal Of Medical Microbiology. - 2009. - 58(1). - P. 125-131.

34. Scheid, P. Acanthamoeba spp. as vehicle and reservoir of adenoviruses / Scheid, P., \& Schwarzenberger, R // Parasitology Research. - 2012. - 111(1). - P. 479-485.

35. Staggemeier, R. Detection and quantification of human adenovirus genomes in Acanthamoeba isolated from swimming pools / Staggemeier, R., Arantes, T., Caumo, K., Rott, M., \& Spilki,F. // Anais Da Academia Brasileira De Ciências. - 2016. - 88(suppl 1). - P. 635-641.

36. Lorenzo-Morales, J. Detection of Four Adenovirus Serotypes within Water-Isolated Strains of Acanthamoeba in the Canary Islands, Spain / Lorenzo-Morales, J., Valladares, B., Martínez-Carretero, E., Maciver, S., \& Coronado-Álvarez, N. // The American Journal Of Tropical Medicine And Hygiene. - 2007. - 77(4). - P. 753-756

37. Hsueh, T. Interactions between Human Norovirus Surrogates and Acanthamoeba spp / Hsueh, T., \& Gibson, K. // Applied And Environmental Microbiology. - 2015. - 81(12). - P. 4005-4013.

38. Mattana, A. Acanthamoeba castellanii Promotion of In Vitro Survival and Transmission of Coxsackie B3 Viruses / Mattana, A., Serra, C., Mariotti, E., Delogu, G., Fiori, P., \& Cappuccinelli, P. // Eukaryotic Cell. - 2006. - 5(4). - P. 665-671.

39. Alotaibi, M. Internalisation of Enteric Viruses by Acanthamoeba castellanii, via Ingestion of Virus-Infected Mammalian Cells / Alotaibi, M. // Food and Environmental Virology. - 2011. - 3(3-4) . - P. 109-114/

40. Danes L. Survival of polioviruses and echoviruses in Acanthamoeba castellanii cultivated in vitro / Danes L. Cerva L. / Journal of Hygiene, Epidemiology, Microbiology, and Immunology. - 1981. $-25(2)$. P. $169-174$

8. Avalos-Padilla, Y., Knorr, R., Javier-Reyna, R., García-Rivera, G., Lipowsky, R., Dimova, R., \& Orozco, E. (2018). The Conserved ESCRT-III Machinery Participates in the Phagocytosis of Entamoeba histolytica. Frontiers in Cellular and Infection Microbiology, 8. doi: 10.3389/fcimb.2018.00053

9. Siddiqui, R., \& Khan, N. (2012). Acanthamoeba is an evolutionary ancestor of macrophages: A myth or reality? Experimental Parasitology, 130 (2), 95-97. doi: 10.1016/j.exppara.2011.11.005

10. Cosson, P., \& Lima, W. (2014). Intracellular killing of bacteria: is Dictyosteliuma model macrophage or an alien? Cellular Microbiology, 16 (6), 816-823. doi: 10.1111/cmi.12291

11. Maisonneuve, E., Cateau, E., Leveque, N., Kaaki, S., BebyDefaux, A., \& Rodier, M. (2017). Acanthamoeba castellanii is not be an adequate model to study human adenovirus interactions with macrophagic cells. PLOS ONE, 12 (6), e0178629. doi: 10.1371/journal. pone.0178629

12. Barker, J., \& Brown, M. (1994). Trojan horses of the microbial world: protozoa and the survival of bacterial pathogens in the environment. Microbiology, 140 (6), 1253-1259. doi: 10.1099/00221287140-6-1253

13. Molmeret, M., Horn, M., Wagner, M., Santic, M., \& Abu Kwaik, Y. (2005). Amoebae as training grounds for intracellular bacterial pathogens. Applied and Environmental Microbiology, 71 (1), 20-28. doi: 10.1128/aem.71.1.20-28.2005

14. Matin, A., \& Jung, S. (2011). Interaction of Escherichia coli K1 and K5 with Acanthamoeba castellanii Trophozoites and cysts. 
The Korean Journal of Parasitology, 49 (4), 349. doi: 10.3347/ kjp.2011.49.4.349

15. Mehmood, K., Gul, N., Jung, S.Y., \& Matin, A. (2012). Escherichia coli $\mathrm{K} 5$ and type III secretion systems mutant interactions with Acanthamoeba (T4 genotype). Adv. Lab. Med. Int., 2 (1), 25-39.

16. Tezcan-Merdol, D., Ljungstrom, M., Winiecka-Krusnell, J., Linder, E., Engstrand, L., \& Rhen, M. (2004). Uptake and replication of Salmonella enterica in Acanthamoeba rhysodes. Applied and Environmental Microbiology, 70 (6), 3706-3714. doi: 10.1128/ aem.70.6.3706-3714.2004

17. Douesnard-Malo, F., \& Daigle, F. (2011). Increased Persistence of Salmonella enterica Serovar Typhi in the presence of Acanthamoeba castellanii. Applied and Environmental Microbiology, 77 (21), 76407646. doi: 10.1128/aem.00699-11

18. Saeed, A., Abd, H., Edvinsson, B., \& Sandström, G. (2008). Acanthamoeba castellanii an environmental host for Shigella dysenteriae and Shigella sonnei. Archives of Microbiology, 191 (1), 83-88. doi: 10.1007/s00203-008-0422-2

19. Saeed, A., Johansson, D., Sandström, G., \& Abd, H. (2012). Temperature depended role of Shigella flexneri invasion plasmid on the interaction with Acanthamoeba castellanii. International Journal of Microbiology, 1-8. doi: 10.1155/2012/917031

20. Anand, C., Skinner, A., Malic, A., \& Kurtz, J. (1983). Interaction of L. pneumophila and a free-living amoeba (Acanthamoeba palestinensis). Journal of Hygiene, 91 (02), 167-178. doi: 10.1017/ s0022172400060174

21. Harold King, C., \& Barry, S. Fields (1991). Effects of Cytochalasin D and Methylamine on intracellular growth of Legionella pneumophila in amoebae and human monocyte-like cells, Infection and Immunity, 59 (3), 758-763.

22. Mengue, L., Régnacq, M., Aucher, W., Portier, E., Héchard, Y., \& Samba-Louaka, A. (2016). Legionella pneumophila prevents proliferation of its natural host Acanthamoeba castellanii. Scientific Reports, 6 (1). doi: 10.1038/srep36448

23. Adeleke, A. (1996). Legionella-like amebal pathogens - phylogenetic status and possible role in respiratory disease. Emerging Infectious Diseases, 2 (3), 225-230. doi: 10.3201/eid0203.960311

24. Mba Medie, F., Ben Salah, I., Henrissat, B., Raoult, D., \& Drancourt, M. (2011). Mycobacterium tuberculosis complex mycobacteria as amoeba-resistant organisms. Plos ONE, 6 (6), e20499. doi: 10.1371/ journal.pone.0020499

25. Samba-Louaka, A., Robino, E., Cochard, T., Branger, M., Delafont, V., \& Aucher, W. (2018). Environmental mycobacterium avium subsp. paratuberculosis hosted by free-living amoebae. Frontiers in Cellular and Infection Microbiology, 8. doi: 10.3389/fcimb.2018.00028

26. Wheat, W., Casali, A., Thomas, V., Spencer, J., Lahiri, R., \& Williams, D. (2014). Long-term survival and virulence of mycobacterium leprae in amoebal cysts. Plos Neglected Tropical Diseases, 8 (12), e3405. doi: 10.1371/journal.pntd.0003405

27. Lamrabet, O., Medie, F., \& Drancourt, M. (2012). Acanthamoeba polyphaga-Enhanced Growth of Mycobacterium smegmatis. Plos ONE, 7(1), e29833. doi: 10.1371/journal.pone.0029833

28. Sanchez-Hidalgo, A., Obregón-Henao, A., Wheat, W., Jackson, M., \& Gonzalez-Juarrero, M. (2017). Mycobacterium bovis hosted by free-living-amoebae permits their long-term persistence survival outside of host mammalian cells and remain capable of transmitting disease to mice. Environmental Microbiology, 19 (10), 4010-4021. doi: 10.1111/1462-2920.13810

29. Pukatzki, S., Kessin, R., \& Mekalanos, J. (2002). The human pathogen Pseudomonas aeruginosa utilizes conserved virulence pathways to infect the social amoeba Dictyostelium discoideum. Proceedings of the National Academy of Sciences, 99 (5), 3159-3164. doi: 10.1073/pnas.052704399

30. de Souza, T., Soares, S., Benitez, L., \& Rott, M. (2017). Interaction between Methicillin-resistant Staphylococcus aureus (MRSA) and Acanthamoeba polyphaga. Current Microbiology, 74 (5), 541-549. doi: 10.1007/s00284-017-1196-z

31. Siddiqui, R., Yee Ong, T., Jung, S., \& Khan, N. (2017). Acanthamoeba castellanii interactions with Streptococcus pneumoniae and Streptococcus pyogenes. Experimental Parasitology, 183, 128-132. doi: 10.1016/j.exppara.2017.08.005

32. Abd, H., Saeed, A., Weintraub, A., Nair, G., \& Sandstrom, G. (2007). Vibrio cholerae $\mathrm{O} 1$ strains are facultative intracellular bacteria, able to survive and multiply symbiotically inside the aquatic free-living amoeba Acanthamoeba castellanii. FEMS Microbiology Ecology, 60 (1), 33-39. doi: 10.1111/j.1574-6941.2006.00254.x

33. Abd, H., Saeed, A., Weintraub, A., \& Sandstrom, G. (2009). Vibrio cholerae O139 requires neither capsule nor LPS O side chain to grow inside Acanthamoeba castellanii. Journal of Medical Microbiology, 58 (1), 125-131. doi: 10.1099/jmm.0.004721-0

34. Scheid, P., \& Schwarzenberger, R. (2012). Acanthamoeba spp. as vehicle and reservoir of adenoviruses. Parasitology Research, 111 (1), 479-485. doi: 10.1007/s00436-012-2828-7

35. Staggemeier, R., Arantes, T., Caumo, K., Rott, M., \& Spilki, F. (2016). Detection and quantification of human adenovirus genomes in Acanthamoeba isolated from swimming pools. Anais Da Academia Brasileira De Ciências, 88 (Suppl. 1), 635-641. doi: 10.1590/00013765201620150151

36. Lorenzo-Morales, J., Valladares, B., Martínez-Carretero, E., Maciver, S., \& Coronado-Álvarez, N. (2007). Detection of four Adenovirus serotypes within water-isolated strains of Acanthamoeba in the Canary Islands, Spain. The American Journal of Tropical Medicine and Hygiene, 77 (4), 753-756. doi: 10.4269/ajtmh.2007.77.753

37. Hsueh, T., \& Gibson, K. (2015). Interactions between human Norovirus surrogates and Acanthamoeba spp. Applied and Environmental Microbiology, 81 (12), 4005-4013. doi: 10.1128/aem.00649-15

38. Mattana, A., Serra, C., Mariotti, E., Delogu, G., Fiori, P., \& Cappuccinelli, P. (2006). Acanthamoeba castellanii promotion of in vitro survival and transmission of Coxsackie B3 viruses. Eukaryotic Cell, 5 (4), 665-671. doi: 10.1128/ec.5.4.665-671.2006

39. Alotaibi, M. (2011). Internalisation of enteric viruses by Acanthamoeba castellanii, via ingestion of virus-infected Mammalian cells. Food and Environmental Virology, 3 (3-4), 109-114. doi: $10.1007 /$ s12560-011-9067-4.

40. Danes, L., \& Cerva, L. (1981) Survival of polioviruses and echoviruses in Acanthamoeba castellanii cultivated in vitro. Journal of Hygiene, Epidemiology, Microbiology, and Immunology, 25 (2), 169-174. 


\section{ОГЛЯДИ ТА ЛЕКЦІї}

\section{ACANTHAMOEBAE AS RESERVOIR OF PATHOGENIC BACTERIA AND VIRUSES}

\section{A.P. Chobotar}

O. Bohomolets National Medical University

SUMMARY. The literature rewiew is showed free-living protozoa genus Acanthamoeba are representatives of large numbers of microecological groups in environmental objects and they constantly interact with other microorganisms (viruses and bacteria) that inhabit these ecological niches. The features of these relationships have been studied for over 20 years. A number of pathogenic and opportunistic bacteria that can coexist with acanthamoebae are investigated. For example, the symbiotic interaction of amoeba with enterobacteria, mycobacteria, legionella, pseudomonadae, staphylococci, streptococci and a number of other prokaryotes is described. When co-cultivating the protozoa with bacteria increases the survival time of the latest and their resistance to the influence of harmful environmental factors. A number of scientific papers are also devoted to the study of the interaction of Acanthamoeba sp. with the representatives of the kingdom of Vira, especially the genera Adenovirus, Norfolkvirus, Rotavirus and Enterovirus. The nature of the interaction of bacteria and viruses with representatives of free-living protozoa on the cellular level is most often studied by using microscopic and modern molecular genetic methods. It is also proved that free-living amoebae can serve as a reservoir for pathogenic microorganisms and serve as a vector for the transmission of pathogens of infectious diseases.

Key words: Acanthamoeba sp.; coexistence; bacteria; viruses.

\section{Відомості про автора:}

Чоботар Анастасія Павлівна - аспірант, Національний медичний університет імені О.О. Богомольця, кафедра мікробіології, вірусології та імунології; anastach16@gmail. com

Information about author:

Chobotar A.P. - PhD student, O. Bohomolets National Medical University, Department of Microbiology, Virology and Immunology; anastach16@gmail.com

Конорлікт інтересів: немає.

Author has no conflict of interest to declare.

Отримано 11.02.2019 p. 